\title{
Once more with emphasis: Two internal thoracic artery grafts are even better than one!
}

\author{
Timothy J. Gardner, MD
}

\footnotetext{
From the Department of Surgery, The Stanley Kimmel Medical College of Jefferson University, Philadelphia, Pa; the Center for Heart and Vascular Health, Christiana Care Health System, Newark, Del; and the Value Institute at Christiana Care Health System, Newark, Del.

Disclosures: Author has nothing to disclose with regard to commercial support.

Received for publication May 14, 2015; accepted for publication May 15, 2015; available ahead of print June 11, 2015.

Address for reprints: Timothy J. Gardner, MD, Center for Heart \& Vascular Health, Christiana Hospital, Suite 103, PO Box 6001, Newark DE 19718 (E-mail: tgardner@christianacare.org).

J Thorac Cardiovasc Surg 2015;150:454-5

$0022-5223 / \$ 36.00$

Copyright $\subset 2015$ by The American Association for Thoracic Surgery

http://dx.doi.org/10.1016/j.jtcvs.2015.05.044
}

In this issue of the Journal, Medalion and associates ${ }^{1}$ in Tel Aviv describe their experience with coronary artery bypass grafting $(\mathrm{CABG})$ in older patients. Their report supports the aggressive use of arterial grafts, in particular bilateral internal thoracic artery (ITA) grafts, whenever feasible, regardless of the age of the patient. Medalion and associates ${ }^{1}$ point out early in this article that evidence for the benefit of the left ITA graft to the left anterior coronary artery was demonstrated more than 30 years ago and validated often since then. ${ }^{2,3}$ Confirmation of the similar benefit of using both thoracic arteries when grafting patients with multivessel coronary artery disease (CAD) has been presented, published, and promoted for many years as well. ${ }^{4-}$ 6 CABG surgeon experts from around the world have championed the use of bilateral ITA grafts whenever feasible, primarily because of the demonstrable improvement in late patency of ITA relative to saphenous vein grafts. ${ }^{7}$

Despite all this compelling evidence favoring arterial grafts, in particular the improved outcomes in patients receiving bilateral ITA grafts, many surgeons have resisted using the right ITA as a second arterial graft in patients with multivessel CAD. The good news for patients with CAD today who require $\mathrm{CABG}$ is that virtually all coronary surgeons worldwide will place the left ITA graft to an obstructed left anterior descending coronary artery. The bad news is that despite all the evidence supporting the use of the right ITA as a graft primarily to the circumflex coronary artery distribution, there are still relatively few patients, especially in the United States, who receive bilateral ITA grafts despite favorable anatomy for this conduit configuration. ${ }^{8,9}$ How can this neglect of the right ITA graft be explained?

There have been specific concerns raised through the years about the safety of bilateral ITA grafts, and these have provided "plausible deniability" for surgeons who have resisted using the right ITA as a graft. An early concern was that bilateral ITA grafting increased the occurrence of sternal healing failure or sternal wound infections. ${ }^{10}$ Improvements in harvesting techniques and the avoidance

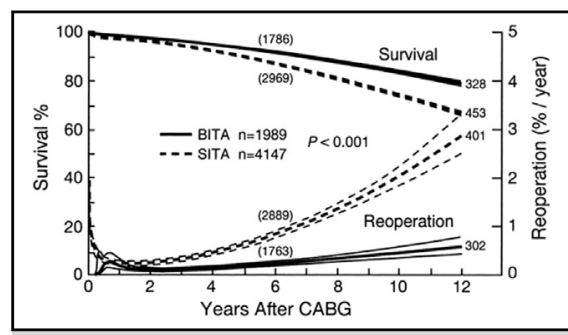

Despite this evidence in 1999, utilization of BITA grafts remains low.

Central Message

Two internal thoracic artery grafts are the best grafting option for patients with multivessel disease, regardless of age. Bilateral internal thoracic artery grafts are both safe and effective.

See Article page 607

of right ITA harvest in a very few select patients, primarily those with severe obstructive lung disease, have led to minimal a priori contraindications for bilateral ITA use. Even patients with diabetes have been shown to tolerate bilateral ITA harvest when this is accomplished with limited chest wall tissue trauma. ${ }^{11}$ How to configure the right ITA within the mediastinum, the best choice of target coronary artery, and other clinical and technical questions have been evaluated and discussed widely and frequently by cardiac surgeons throughout the world.

Although there are few remaining "good excuses" for not implanting bilateral ITA grafts in most patients with multivessel CAD, the "patient is too old to benefit from bilateral ITAs" argument continues to provide some surgeons with a rationale for failing to use a right ITA graft. Refuting this last-ditch excuse for underutilization of bilateral ITA grafts in older patients is the primary message to be taken from this impressive series by Medalion and associates. ${ }^{1}$

Because the superiority of an ITA graft relative to a saphenous vein graft includes better early as well as late graft patency, it never has made sense to deny older patients arterial grafts on the basis that they might not survive long enough to benefit from the second arterial graft. In this report of CABG surgery performed during the past 2 decades in over 1000 patients aged 70 years and older, the rate of bilateral ITA use was a commendable $56 \%$. $^{1}$ Although a few centers have reported an even higher percentage of bilateral ITA graft use, this experience from Israel, in which more than half of older patients undergoing $\mathrm{CABG}$ received bilateral 
ITA grafts, demonstrates excellent patient care because the use of both ITA arteries represents the best grafting option available. Equally notable in this report, and not surprising, are the excellent short and long-term outcomes of the patients who had bilateral ITA grafts. ${ }^{1}$ Although case selection undoubtedly accounts for some differences in outcomes among patient groups and favors the patients receiving bilateral grafts in this series, these excellent results confirm both safety and efficacy in these older patients.

Despite the Medalion and associates' use of propensity matching, ${ }^{1}$ always a challenge when relying on diverse and archived patient records, the jury is still out regarding the superiority of radial artery grafting across the board relative to saphenous vein grafts in the older population. What is clear from this report, as accurately stated by Medalion and associates, ${ }^{1}$ is that the use of bilateral ITA grafts in older patients is both safe and efficacious. Acknowledging that surgeons have many individual clinical considerations for optimal graft selection when evaluating patients for CABG, there are few remaining excuses for failing to use bilateral ITA grafts whenever feasible and appropriate. The time has come for all CABG surgeons, including those in North America where there has been a low percentage of bilateral ITA graft utilization, to take whatever extra operative time is required to provide patients with multivessel CAD with bilateral ITA grafts whenever clinically appropriate.

\section{References}

1. Medalion B, Mohr R, Ben-Gal Y, Nesher N, Kramer A, Eliyahi S, et al. Arterial CABG is safe and effective in elderly patients. J Thorac Cardiovasc Surg. 2015; 150:607-12.

2. Loop FD, Lytle BW, Cosgrove DM, Stewart RW, Goormastic M, Williams GW, et al. Influence of the internal-mammary-artery graft on 10-year survival and other cardiac events. N Engl J Med. 1986;314:1-6.

3. BARI Investigators. The final 10-year follow-up results from the BARI randomized trial. J Am Coll Cardiol. 2007;49:1600-6.

4. Lytle BW, Blackstone EH, Loop FD, Houghtaling PL, Arnold JH, Akhrass R, et al. Two internal thoracic artery grafts are better than one. J Thorac Cardiovasc Surg. 1999; 117:855-72.

5. Taggart DP, D'Amico R, Altman DG. The effect of arterial revascularisation on survival: a systematic review of studies comparing bilateral and single internal mammary arteries. Lancet. 2001;358:870-5.

6. Taggart DP, Altman DG, Gray AM, Lees B, Nugara F, Yu LM, et al. Randomized trial to compare bilateral vs. single internal mammary artery grafting: 1-year results of the Arterial Revascularisation Trial (ART). Eur Heart J. 2010;31: 2470-81.

7. Benedetto U, Amrani M, Gaer J, Bahrami T, de Robertis F, Simon AR, et al; Harefield Cardiac Outcomes Research Group. The influence of bilateral interna mammary arteries on short- and long-term outcomes: a propensity score matching in accordance with current recommendations. J Thorac Cardiovasc Surg. 2014;148:2699-705

8. Tatoulis J, Buxton BF, Fuller JA. The right internal thoracic artery: the forgotten conduit-5,766 patients and 991 angiograms. Ann Thorac Surg. 2011;92:9-15; discussion 15-17.

9. Itagaki S, Cavallaro P, Adams DH, Chikwe J. Bilateral internal mammary artery grafts, mortality and morbidity: an analysis of 1,526,360 coronary bypass operations. Heart. 2013;99:849-53.

10. Grossi EA, Esposito R, Harris LJ, Crooke GA, Galloway AC, Colvin SB, et al Sternal wound infections and the use of internal mammary artery grafts. J Thorac Cardiovasc Surg. 1991;102:342-6; discussion 346-7.

11. Deo SV, Shah IK, Dunlay SM, Erwin PJ, Locker C, Altarabsheh SL, et al. Bilateral internal thoracic artery harvest and deep sternal wound infection in diabetic patients. Ann Thorac Surg. 2013;95:862-9. 